\title{
Percutaneous coronary interventions in children with structurally normal hearts. Is there any place for stenting?
}

\author{
Jaouadi Abdelaziz, Jamel Ahmad, Abdallah Maroua, Messaoudi Yosra, \\ Ibn Ezzine Bilel, Ben Halima Nejeh
}

Cardiology Department, Ibn El Jazzar University Hospital, Kairouan, Tunisia 3100

ARTICLE INFO

Article history:

Submitted: 10. 8. 2019

Revised: 21. 4. 2020

Accepted: 24. 4. 2020

Available online: 8. 2. 2021

Klíčová slova:

Akutní koronární syndrom

Angioplastika

Dětství

\section{SOUHRN}

Úvod: Akutní koronární syndromy (AKS) se sice vyskytují mnohem častěji v dospělosti než v dětství, přičemž vrozená koronární insuficience hraje významnou úlohu (zvláště po operaci, tzn. TGA po arteriálním switchi), avšak AKS u strukturálně zdravého srdce souvisí častěji se systémovými poruchami a/nebo lokoregionálními anomáliemi epikardu věnčitých tepen. I když perkutánní koronární angioplastika (percutaneous coronary angioplasty, PCA) má nesmírný význam u dospělých po AKS, zvláště při implantaci stentu snižující následnou mortalitu, u dětí se nejedná o běžný výkon a vzhledem k možným komplikacím se provádí velmi zř́́dka u kojenců.

Pacienti a metody: $V$ této kazuistice chceme představit tři klinické případy pacientů mladších 18 let se strukturálně zdravým srdcem, kteří prodělali AKS a u nichž byla provedena perkutánní koronární angioplastika. Cíl naší kazuistiky: $V$ naší práci chceme popsat náročnou diagnostiku a řešení AKS ve výše uvedené specifické populaci i účinnost koronární angioplastiky s předpokládanými komplikacemi a probrat postavení implantace stentu jako léčebné možnosti.

Výsledky: U tří pacientů po AKS s elevací úseku ST ve věku 4, 10 a 12 let byla provedena perkutánní koronární intervence. $V$ jednom prípadě byla za etiologický faktor označena Kawasakiho choroba a ve dvou př́padech familiární hypercholesterolemie.

Koronarografické vyšetření prokázalo ve všech případech významnou stenózu levých věnčitých tepen.

Ve dvou prípadech byla úspěšně provedena angioplastika s implantací stentu a v jednom prípadě balonková angioplastika.

Během sledování těchto pacientů nebyly prokázány žádné recidivy ani komplikace v souvislosti s PCA.

Závěr: Koronární angioplastika může představovat schůdnou strategii u kojenců a dětí s ucpanými tepnami nebo dysfunkcí levé komory srdeční i alternativu chirurgické revaskularizace a transplantace srdce před dosažením vyššího věku; nicméně vzhledem k vyššímu riziku v souvislosti s PCA a obtižné srdeční katetrizaci zůstává tématem, u něhož dosud nebylo dosaženo jednotného názoru.

() 2021, ČKS.

\section{ABSTRACT}

Introduction: Acute coronary syndromes (ACS) are far more common in adulthood than in childhood, congenitally related coronary insufficiency occupies a convenient part (especially after surgical repair, i.e. TGA arterial switch) but ACS in structurally normal hearts are more common related to systemic disorders and/ or loco-regional epicardial coronary anomalies. Although, percutaneous coronary angioplasty (PCA) is paramount in adults who have had an acute coronary syndrome especially with stent implantation reducing the consequent mortality, it's not a common option in children and extremely rare in infants considering the complications that can be incurred.

Patients and methods: We aim to report three clinical cases of structurally normal hearts in patients aged less than 18 years in this study who experienced an acute coronary syndrome and underwent a percutaneous coronary angioplasty

Aim of the case presentations: We aim to study through this work the challenging courses of the diagnosis and the management of ACS in this specific population and the efficacy of coronary angioplasty with its suspected complication as well as to discuss the place of stenting as therapeutic option.

Results: Three patients aged respectively 4, 10, and 12 years underwent percutaneous coronary intervention after an acute coronary syndrome with ST segment elevation related to Kawasaki disease in one case and to familial hypercholesterolemia in the other cases. 
Coronary angiography showed a significant stenosis in the left coronary arteries in all cases.

Successful angioplasty with stent implantation was achieved in two cases and a balloon angioplasty was undergone in one case.

Keywords:

Acute coronary syndrome Angioplasty

Childhood
The follow up of these patients did not show any recurrences or complications related to the PCA.

Conclusion: Coronary angioplasty can be a viable strategy for infants and children with blocked arteries or a left ventricle dysfunction, alternative to surgical revascularization and heart transplantation when they are older, but because of the increased risk of PCA and the difficulty of heart catheterization, it remains a controversial issue.

\section{Introduction}

The diagnosis and management of myocardial ischemia and infarction in children is very challenging as electrical, biological, and echographic criterions are not well defined comparatively to adults. Moreover, acute presentations are often clinically misleading and usually in a substrate of structurally abnormal hearts in a spectrum of specific congenital heart diseases either as initiatory or after surgical repair (i.e. after TGA arterial switch surgery, ALCAPA...). In the absence of congenital heart diseases, acute coronary syndromes are usually related to systemic disorders and/or loco-regional epicardial coronary anomalies. Furthermore, reperfusion strategies are not well established as percutaneous coronary angioplasty (PCA) is not a common option in children and extremely rare in infants considering the complications that could be incurred, as thrombolysis and anti-thrombotic therapy do.

\section{Patients and methods}

We are about to report three cases of patients from the pediatric population aged respectively 4,10 , and 12 years with structurally normal hearts, hospitalized in our department after an acute coronary syndrome for which they underwent coronary angioplasty.

We aim to study through this work the challenging courses of the diagnosis and the management of ACS in this specific population and the efficacy of coronary angioplasty with its suspected complication as well as to discuss the place of stenting as therapeutic option.

\section{Case reports}

\section{Case 1}

A 10 -year-old boy with no medical history born from inbreeding marriage and with a history of sudden death in two of his young brothers at the ages of 9 and 11 years old, presented to the emergency department for acute chest pain and palpitations ongoing for at least three hours.

On examination the patient had tachypnea at 33 cycle/ minute without signs of serious respiratory distress and he was hemodynamically stable (BP at $110 / 80 \mathrm{mmHg}$ ). There were no signs of left or right heart failure, no abnormal cardiac or respiratory murmur. But cutaneous xanthomas were found on his elbows and knees (Fig. 1).

In a per-critic electrocardiogram (Fig. 2) revealed a sinus tachycardia at 110 beats/minute with an ST segment

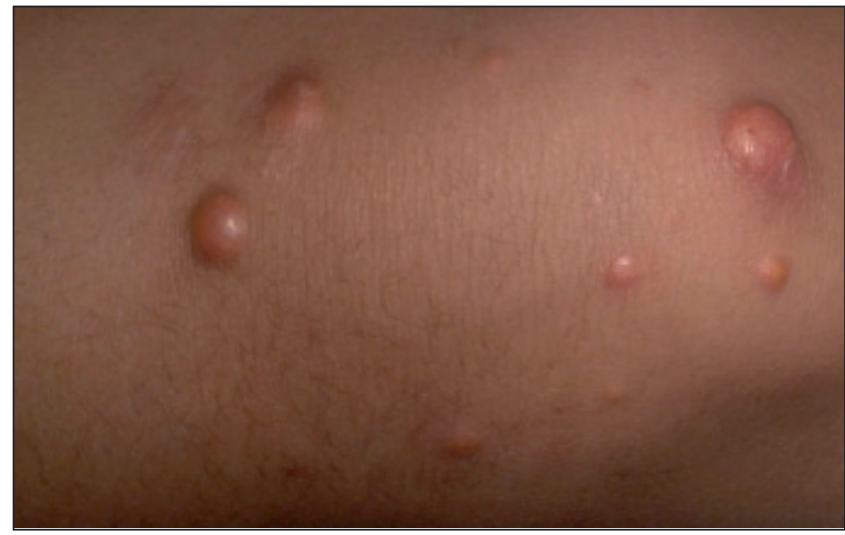

Fig. 1 - About the first case, these are xanthomas in the surface of the patient's right knee.

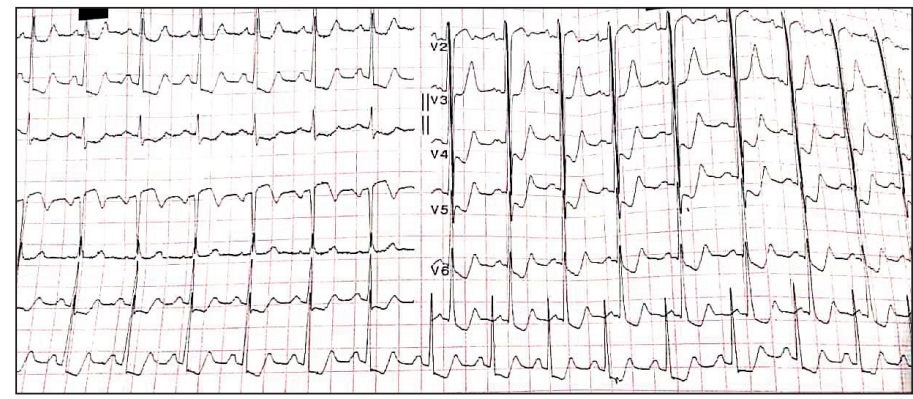

Fig. 2 - ECG of the first case.

depression in the anterior and inferior leads associated to an ST segment elevation in AVR lead. Cardiac enzymes were elevated (troponin $1700 \mathrm{ng} / \mathrm{l}$ ).

The diagnosis of acute coronary syndrome was established, and the young boy was rapidly treated with loading doses of clopidogrel $(300 \mathrm{mg})$, aspirin $(150 \mathrm{mg})$ and $50 \mathrm{mg}$ of UFH (un-fractioned heparin) followed by a progressive disappearance of his chest pain and a medium resolution of ST segment changes in the electrocardiogram. The decision was to exceed the acute course for further evaluation of the underlying situation.

After 36 hours, a CT coronary angiography was performed and had revealed a significant and long stenosis of the left main artery (LMA).

Our heart team decided to perform a percutaneous revascularization with simple balloon angioplasty and stent implantation that was done with satisfying results.

In the screening exams, LDL cholesterol level was at $12 \mathrm{mmol} / \mathrm{l}$. The diagnosis of familial hypercholesterolemia was established based on familial history of sudden deaths, xanthomas on the clinical exam and biological 
screening. Thus, the patient was treated with $10 \mathrm{mg}$ of rosuvastatin in the association with diet and healthy lifestyle.

After 2 months of follow up, the young boy didn't show any complication (especially from PCA) and family screening is still ongoing, but LDL level persisted at high levels, so an increasing in statin doses was prescribed and he was referred to a dietitian.

\section{Case 2}

A 12-year-old boy with a family history of coronaropathy and type 1 diabetes, but full metabolic screening was not attempt for him or his family previously, presented to the emergency department for abrupt chest pain and vomiting. His heart rate was at 100 beats/min without signs of heart failure and there was no clinical evidence for low cardiac output.

The diagnosis of ACS with ST segment elevation was deducted after the electrocardiogram showed an ST segment elevation on lateral leads of $1.5 \mathrm{~mm}$ with a mirror image on inferior leads.

The echocardiogram revealed a severe hypokinetic lateral free wall and $50 \%$ of ejection fraction without coronary anomalies and valvular diseases. Infarct biomarkers were extremely elevated (troponin level was at $2500 \mathrm{ng} / \mathrm{l}$ ).

Fibrinolysis with $30 \mathrm{mg}$ of tenecteplase was attempted but failed. So, rescue percutaneous coronary intervention was performed urgently and revealed an ostial total occlusion of the circumflex artery (the left anterior descending artery and the right artery were infiltrated without significant stenosis). The decision was to undertake the occlusion for a balloon angioplasty followed by stenting with a self-expandable stent of $3 \times 20 \mathrm{~mm}$.

In the aftermath of the procedure the chest pain disappeared as well as the ST segment elevation. The administration of double antiplatelet therapy, betablockers, and statin as initiated in the boy.

In the follow up screening a familial hypercholesterolemia was diagnosed when a high total cholesterol ( $>20$ $\mathrm{mmol} / \mathrm{l}$ ) and LDL cholesterol (between 13 and $16 \mathrm{mmol} / \mathrm{l}$ ) levels in screening exams for the patient as well as his parents, brothers and paternal cousins. Genetic testing was performed and diagnosed heterozygote familial hypercholesterolemia. After 3 years of the angioplasty, there were no complications.

\section{Case 3}

A 4-year-old boy presented to the pediatric emergency department with fever and rash. Kawasaki disease (KD) was suspected, and he was referred to an echocardiography exam for further screening exploration which showed a large aneurysm at the origin of the left anterior descending (LAD) coronary artery measuring $6 \mathrm{~mm}$ in diameter and a slight dilatation of the circumflex coronary artery $(\mathrm{Cx})$ but the right coronary artery was not dilated.

Thus, KD was confirmed and the boy was treated with infusion of intravenous immunoglobulin (IVIG) and highdose aspirin ( $80 \mathrm{mg} / \mathrm{kg} /$ day).

Despite therapy with IVIG, there was enlargement of his coronary aneurysms reaching $8 \mathrm{~mm}$ and the RCA became dilated measuring $7 \mathrm{~mm}$. After a pulse dose of IVIG he became apyretic and there was a significant de-

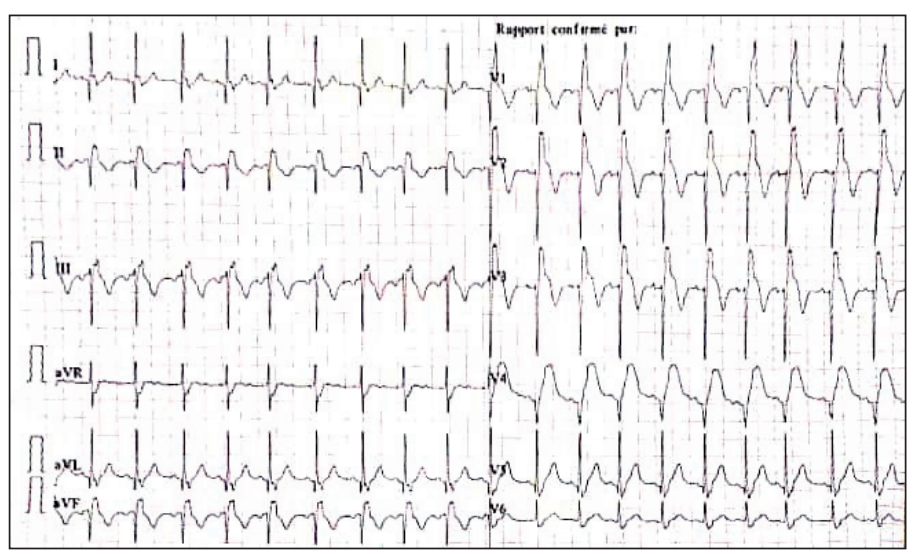

Fig. 3 - ECG of the third case.

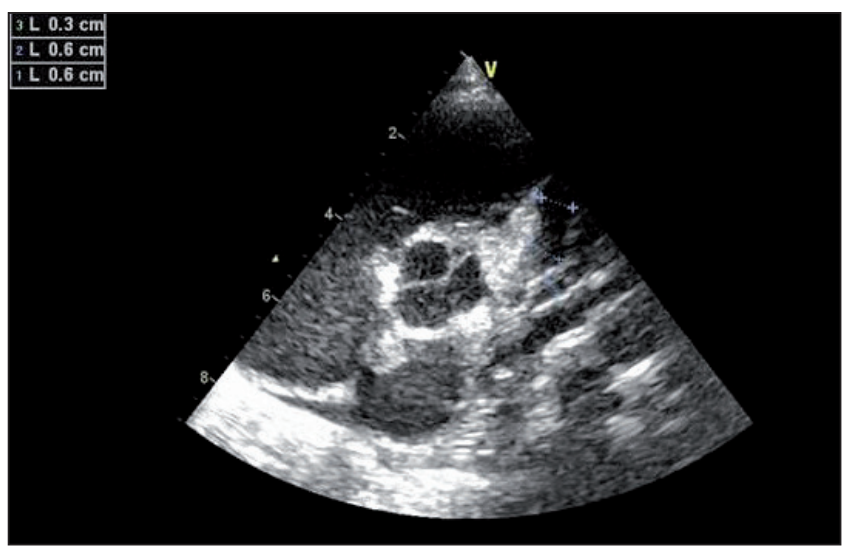

Fig. 4 - Short axis echo view of the third case.

crease in the inflammatory marquers. The patient was discharged home on subcutaneous low-molecular-weight heparin and aspirin ( 6 weeks after the beginning of his symptoms).

Two weeks later, he was admitted with chest pain. Anamnesis revealed that anticoagulation therapy had been inadequate during the previous week. The patient underwent an electrocardiogram which was consistent with anterior myocardial ischemia (Fig. 3).

TTE showed apical and septal hypokinesis with poor left ventricle function and moderate mitral regurgitation (ejection fraction $=35 \%$ ) associated to an ostial LAD aneurysm occluded with a large thrombus (Fig. 4).

The patient received $37.5 \mathrm{mg}$ of clopidogrel and he was maintained with a heparin infusion of $15 \mathrm{U} / \mathrm{kg} / \mathrm{h}$, after few minutes a complete AV block occurred.

The decision was to put the patient on dobutamine and a 0.7-unit dose of tenecteplase (metalyse) was infused intravenously. Then the patient was transferred directly to the cardiac catheterization laboratory for urgent evaluation and treatment.

A left heart catheterization was performed via the right femoral artery. The aortic pressure was $85 / 55 \mathrm{mmHg}$. Non-selective angiography of the left coronary artery was performed which showed a complete occlusion of this artery (Fig. 5), so an infusion of heparin (50 mg) was administered followed by balloon angioplasty.

This procedure was well tolerated and recanalization with complete reperfusion of the occluded artery was im- 


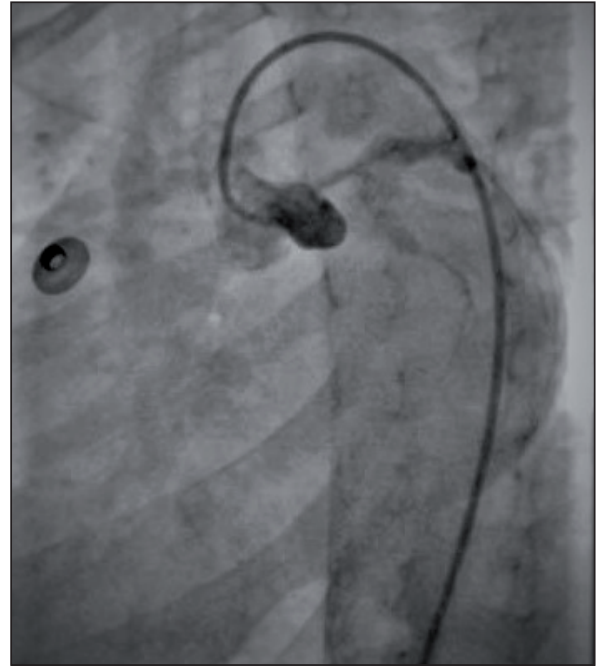

Fig. 5 - Caudal fluoroscopy view of coronary arteries of the third case.

mediately achieved. Angiography into the RCA then was performed to show an extreme aneurysmal artery from the proximal to the distal branches.

The heart block resolved 2 days later, the boy improved clinically and was discharged 15 days later receiving clopidogrel, aspirin, and acenocoumarol (mini-sintrom).

A follow up echocardiogram showed an improvement of left ventricular contraction reaching 53\% after a few weeks and further investigation didn't reveal other arterial obstruction.

\section{Discussion}

Coronary catheterization represents the common technique for angiography since October 1958 by F. Mason Sones. First percutaneous coronary angioplasty was performed in September 1977 by Grüntzig at a 38-year-old patient with a high-grade discrete stenosis of the proximal left anterior descending coronary artery.

Since then, percutaneous coronary intervention $(\mathrm{PCI})$ is commonly used in adult patients with coronary artery disease (CAD) either in acute coronary syndromes, stable or unstable angina or ischemic heart failure and its efficacy was revolutionary.

Despite the diversity of procedural indications, the goals of $\mathrm{PCl}$ and techniques remain the same in either an adult or a child: to relieve symptoms of angina, and to reverse or prevent ischemia, infarction, or sudden death. ${ }^{1}$ Available literature suggests that $\mathrm{PCl}$ is feasible from infancy to adolescence. ${ }^{2-8}$

Data on $\mathrm{PCl}$ in children and adolescents remain limited. This reflects not only the relative health of the younger patient population, but also the technical challenges inherent to these procedures in smaller patients. ${ }^{3,6,9}$

Nevertheless, due to the smaller vessel diameter, coronary interventions in children and especially infants bear a high risk of complications. Even temporary occlusion withthin catheters ( 3 or 4 French) can cause ST segment alterations in the ECG and arrhythmia. More severe com- plications are thrombus formation or thromboembolism, rupture of the vessel, or creation of an intimal flap causing reduced myocardial perfusion and infarction. ${ }^{10,11}$

However, $\mathrm{PCl}$ in this population of patients can be a feasible strategy especially in acute coronary syndromes when medical therapy (anticoagulation and anti-aggregation therapy) and thrombolysis fails. Balloon dilation or, if necessary, stenting of coronary arteries stenosis to restore adequate myocardial perfusion, is feasible even in small children with a low bodyweight. ${ }^{10}$

Acute coronary syndromes in children and infants are rare and secondary to many causes such as arteritis (Takayasu, Kawasaki...), spontaneous coronary dissection, congenital aneurysms, metabolic disorders (some familial hypercholesterolemia, nephrotic syndromes...) and post-transplant coronary vasculopathy in some abnormal coronary origins. ${ }^{1-8,10-13}$

Congenital heart diseases were excluded from this article, but they occupy an important part of the etiologies as the abnormal left coronary artery originating from the pulmonary artery 'ALCAPA' does which represent the congenital disorder that is most frequently seen in cause of pediatric myocardial infarction with Kawasaki's disease. ${ }^{14}$ In normally structured heart, during childhood and adolescence, causes could be divided into systemic ones with secondary affection of coronary arteries (Kawasaki's disease, vasculitis, genetic diseases causing hypercoagulability, nephrotic syndromes, and familial hyperlipidemia) and/or loco-regional epicardial coronary artery abnormalities (myocarditis, drugs and substances causing coronary spasm, spontaneous dissection, severe myocardial bridging, accelerated atherosclerosis, tumoral and infective embolisms and hypertrophic cardiomyopathy). ${ }^{14}$

Yet, antithrombotic treatment and thrombolysis should be manipulated with caution at this age since that standardized antiplatelet therapy regimens and durations have not yet been established at present.

The choice between simple balloon dilatation and stenting was made most of the time depending to the underline etiology of the coronary syndrome. Aneurysms and dissections related diseases were treated with balloon angioplasty ${ }^{15}$ but those related to a significant coronary artery stenosis were treated with stents. ${ }^{13}$

Some challenges are raised using coronary artery stents among young children. The risk of in-stent restenosis may be increased, either because of the small diameter of the stents required or because of undefined differences in vascular healing responses in this population. ${ }^{10}$

Furthermore, a metallic stent may become undersized because of a child's growth: a 4-fold increase in the diameter of the left main coronary artery (1-4.5 $\mathrm{mm}$ ) occurs between infancy and 17 years of age. ${ }^{16}$ Finally, the presence of a metallic stent may permanently alter the coronary physiology.

Moreover, stents implantations required to maintain dual anti-platelet therapy with aspirin and clopidogrel for at least 12 months unless contraindications are present. Premature termination or suspension of the dual anti-platelet therapy may result in a higher re-stenosis rate or stent thrombosis.

New stent generations were implanted such as selfexpandable stents and bioresorbable scaffolds to avoid 
those risks. ${ }^{13}$ In adult, self-expandable stents are indicated generally in STEMI patients, bifurcation lesions, and situations with no arterial congruence (CABG).

As in our second case, a self-expandable stent was put in a 12-year-old child for a purpose to adjust the stent diameter to the artery wall and to optimize coronary flow meanwhile.

There has been no other case to our knowledge with a coronary self-expandable stent implantation in childhood so far.

\section{Conclusion}

Coronary angioplasty can be a viable strategy for infants and children with blocked arteries or a left ventricle dysfunction, alternative to surgical revascularization and heart transplantation when they are older, but because of the increased risk of PCA and the difficulty of heart catheterization, it remains a controversial issue.

\section{References}

1. Newburger JW, Fulton DR. Coronary revascularization in patients with Kawasaki disease. J Pediatr 2010;157:8-10.

2. Bratincsák A, Salkini A, El-Said HG, Moore JW. Percutaneous stent implantation into coronary arteries in infants. Catheter Cardiovasc Interv 2012;79:303-311.

3. Ashwath R, Gruenstein D, Siwik E. Percutaneous stent placement in children weighing less than 10 kilograms. Pediatr Cardiol 2008;29:562-567.

4. Divekar AA, Lee JJ, Tymchak WJ, Rutledge JM. Percutaneous coronary intervention for extrinsic coronary compression after pulmonary valve replacement. Catheter Cardiovasc Interv 2006;67:482-484.

5. Drossner DM, Chappell C, Rab T, Kim D. Percutaneous coronary intervention for acute myocardial infarction in a pediatric patient with coronary aneurysm and stenosis due to Kawasaki disease. Pediatr Cardiol 2012;33:811-813.

6. Ishii M, Muta H, Nakahata $Y$, et al. Long-term followup results of percutaneous catheter intervention for coronary artery lesions after Kawasaki disease: multicenter collaborative study. Pediatrics 2008;121:S94.

7. Muta H, Ishii M. Percutaneous coronary intervention versus coronary artery bypass grafting for stenotic lesions after Kawasaki disease. J Pediatr 2010;157:120-126.

8. Cai A, Kramer C, Bandisode R, Fernandes VL. Percutaneous Coronary Intervention in an 8-Month-Old Infant for Ostial Stenosis of a Reimplanted Left Main Coronary Artery. Case Rep Cardiol 2018;2018:2512406.

9. Sachdeva R, Seib PM, Frazier EA. Percutaneous coronary intervention using drug-eluting stents in pediatric heart transplant recipients. Pediatr Transplant 2009;13:10141019.

10. Schneider M, Wiebe W, Hraška V, Zartner P. Coronary interventions in congenital heart diseases: from preterm to young adult patients. J Interv Cardiol 2013;26:287-294.

11. Rahman MA, Chaudhury $\mathrm{H}$, Aga N. Child myocardial infarction and follow-up outcome after revascularization. J Invasive Cardiol 2008;20:37-40.

12. Numan F, Hasanefendioğlu Bayrak A, Cantaşdemir M, et al. Percutaneous transluminal angioplasty in pediatric patients with Takayasu arteritis: comparison of initial and long-term results of interventions. Anadolu Kardiyol Derg 2010;10:281-284.

13. Nazif T, Kalra S, Ali ZA, et al. Percutaneous Coronary Intervention with Bioresorbable Scaffolds in a Young Child. JAMA Cardiol 2017;2:430-434.

14. Meki B, Ture M, Balik H. Myocardial Infarction in Children. In: Pamukçu B (ed.). Myocardial Infarction. IntechOpen 2019. https://doi.org/10.5772/ intechopen.74793

15. Akagi T, Ogawa S, Ino T, et al. Catheter interventional treatment in Kawasaki disease: A report from the Japanese Pediatric Interventional Cardiology Investigation Group. J Pediatr 2000;137:181-186.

16. Oberhoffer $R$, Lang $D$, Feilen $K$. The diameter of coronary arteries in infants and children without heart disease. Eur J Pediatr 1989;148:389-392. 